\title{
Conditions in the Channel Islands during the 1940-45 German Occupation and their impact on the health of islanders A systematic review of published reports and first-hand accounts
}

Rosemary F. Head and George T. H. Ellison

An unhealthy occupation? The Impact of the 1940-45 German Occupation on the Health of Channel Islanders

We're all quite well, but getting thinner,

Not much for tea, still less for dinner.

Though not exactly on our uppers,

We've said Adieu to cold ham suppers.

In peace time those who wished to slim,

Tried diet, massage, baths and gym.

We'll tell the stout of every nation

The secret's solved by Occupation.

[Anon, Jersey (Lainé, 1945)]

\section{Introduction}

The occupation of the British Channel Islands by the German Army is one of the less discussed episodes of the Second World War, not least perhaps because it was something of an embarrassment to the British Government of the time. ${ }^{1}$ The British Government was forced to order the demilitarisation of the islands, which lie just off the coast of northern France, when the collapse of the

1 Bunting, M. (2004). The Model Occupation: The Channel Islands under German rule 1940-1945. London: Pimlico. 
Maginot line and the retreat of Allied forces to the beaches of Dunkirk meant that occupation became inevitable. ${ }^{2}$ Any attempt to defend the islands would have involved huge loss of life, both military and civilian, and at little strategic gain to the Allies. For this reason they were abandoned to their fate - a fate which involved almost five years of increasing deprivation and misery.

Studies of the impact of conditions during the German occupation of other European countries are plentiful, and suggest that conditions were particularly severe in occupied Russia, where sources speculate that the Leningrad siege may have claimed the lives of up to $50 \%$ of the city's population. ${ }^{3}$ In the Netherlands, German blockades towards the end of 1944 had an immediate effect on the health of the population, leading to an increase in mortality, a decrease in fertility and a reduction in the birth weight of babies. ${ }^{4}$ The occupation of the Channel Islands also involved increasing deprivation, culminating in a siege during the last 10 months of the war when the islands were cut off from mainland France by the Allied advance following the Normandy landings.

As part of a broader programme of research exploring the impact of the occupation on the health of Channel Islanders (the Channel Islands Occupation Birth Cohort Study and related studies; see Ellison et al., 1998 and the Appendix), this paper set out to conduct a systematic review of published sources describing the conditions experienced by Channel Islanders during the 1940-45 occupation and thereby assess the immediate and longer term impact of these conditions on islanders' health.

\section{Methods}

The systematic review applied each of the four key components developed within epidemiology and the applied social sciences for generating explicit secondary syntheses of data from primary sources: a systematic search for relevant published sources with explicit inclusion and exclusion criteria; the critical appraisal of included sources to assess the reliability of the evidence they provide; the extraction of relevant data from each of the included sources; and the collation of extracted data to generate a synthesis of findings. ${ }^{5}$ The systematic search for relevant sources

2 Sanders, P. (2005). The British Channel Islands under German Occupation 1940-45. Jersey: Jersey Heritage Trust.

3 Salisbury, H. E. (2000). The 900 Days: The siege of Leningrad. London: Pan.

4 Stein, Z., Susser, M. (1975). "Fertility, Fecundity, Famine: Food rations in the Dutch Famine 1944-5 have a causal relation to fertility, and probably to fecundity", Human Biology, 47: 131-154.

5 Victor, L. (2008). "Systematic reviewing”, Social Research Update, 54: 1-4. 
used a citation network based on references cited in Madeleine Bunting's recently updated historical account, The Model Occupation (2004), and on references cited in each of these cited sources. Any sources that provided first- or second-hand accounts of conditions and related experiences during the 1940-45 occupation of the Channel Islands were included in the review. The first of these searches generated a total of 12 published histories of the occupation, including several written immediately after the occupation ended and a number of more recent additions. In addition to these formal histories of the occupation, personal memoirs and diaries written by those who experienced the occupation first-hand were obtained from the reference lists of works identified through the citation network and from a systematic search of the comprehensive collection of published and unpublished material on the occupation held by the Guernsey Island Archives Service. ${ }^{6}$ A total of 11 such memoirs and diaries were obtained, and these also included those contemporary to the occupation and those published more recently. Meanwhile, the search of the Guernsey archives also uncovered wartime recipes and health reports, as well as two official reports compiled by the Guernsey Controlling Committee - the civilian "cabinet" that assumed emergency administrative powers in the run-up to the occupation and thereafter ${ }^{7}-$ and four academic papers and theses examining the occupation of the Channel Islands.

A total of 30 sources were therefore consulted for information relating to the occupation of the Channel Islands (a complete list of these can be found in Table 1). During the critical appraisal and extraction of data provided by each of the included sources, details such as the rationing of foodstuffs, the dates on which specific events occurred, and the nature of conditions on the islands were crosschecked and validated between sources prior to synthesis. Critical appraisal confirmed that much of the material contained in these sources was essentially anecdotal and was therefore of limited reliability. For this reason the data extracted from these sources were treated with caution and only included in those aspects of the synthesis that are essentially speculative. Nonetheless, wherever possible the key data presented here were drawn from conditions and events to which more than one source referred, and are therefore most likely to offer valid information on conditions prevailing during the occupation. The following is therefore intended to be a robust account of conditions during the occupation and the reported health consequences of these conditions.

6 http://user.itl.net/-glen/archgsy.html

7 Jeffs, D. (ed.) (1999). One Hundred Years of Health: The changing health of Guernsey 1899-1999. Guernsey: Board of Health. 
Table 1. List of sources used for compilation of the review.

\begin{tabular}{|c|c|c|c|}
\hline Author(s) & Year & Type of Source & Where Extracted From \\
\hline Anquetil & 1990 & Memoir & Reference List \\
\hline Aubin Morris & 1994 & Recipes & Guernsey Archives \\
\hline Bell & 1995 & Published History & Reference List \\
\hline Bichard Plumb & 1958 & Memoir & Reference List \\
\hline Bihet & 1985 & Memoir & Reference List \\
\hline Bihet & 1993 & Memoir & Reference List \\
\hline Bunting & 2004 & Published History & Original source consulted \\
\hline Cruickshank & 1975 & Published History & Reference List \\
\hline Dales & 1995 & Anthology & Guernsey Archives \\
\hline Day & 1995 & Anthology & Guernsey Archives \\
\hline Ellison and Kelly & 2005 & Academic Paper & Guernsey Archives \\
\hline Falla & 1995 & Anthology & Guernsey Archives \\
\hline Hillsdon & 1999 & Anthology & Guernsey Archives \\
\hline Jeffs & 1995 & Anthology & Guernsey Archives \\
\hline Lainé & 1945 & Memoir & Reference List \\
\hline Lainé & 1945 & Committee Report & Guernsey Archives \\
\hline Langlois & 1999 & Academic Paper & Guernsey Archives \\
\hline Le Ruez & 1994 & Memoir & Reference List \\
\hline Leale & 1945 & Committee Report & Guernsey Archives \\
\hline Lewis & 1983 & Memoir & Reference List \\
\hline Maugham & 1946 & Published History & Reference List \\
\hline Mayne & 1945 & Memoir & Reference List \\
\hline McLoughlin & 1995 & Published History & Reference List \\
\hline Mollet & 1954 & Published History & Reference List \\
\hline Ozanne & 1994 & Memoir & Reference List \\
\hline Pipe & 1945 & Academic Paper & Wellcome Library \\
\hline Rivett & 2001 & Published History & Reference List \\
\hline Sanders & 2005 & Published History & Reference List \\
\hline Sinel & 1958 & Published History & Reference List \\
\hline Sinel & 1984 & Memoir & Reference List \\
\hline Stoeckl and Ellison & 2001 & Academic Paper & Guernsey Archives \\
\hline Tabb & 2005 & Published History & Reference List \\
\hline Toms & 1967 & Published History & Reference List \\
\hline Troudeaud & 1990 & Memoir & Reference List \\
\hline Wood and Wood & 1955 & Published History & Reference List \\
\hline
\end{tabular}

\section{Background to the occupation}

The occupation of the Channel Islands (affecting the populations of the two main islands, Jersey and Guernsey, as well as Alderney, which was almost completely evacuated, and the small population of Sark) began at the end of June 1940. Prior to the occupation, large numbers of islanders were evacuated (including men leaving to enlist in the British armed forces), with 17,000 out of a population of about 41,000 leaving Guernsey and 10,000 of a population of about 50,000 leaving 
Jersey. ${ }^{8}$ Children in particular were encouraged to evacuate, and most of the schools in Guernsey evacuated en masse although, again, fewer left Jersey. ${ }^{9}$ Despite its much reduced population, conditions in Guernsey were rapidly to become more severe than those on Jersey due to a more limited capacity for growing food and a larger influx of German soldiers. ${ }^{10}$ In fact, a meeting of doctors in Guernsey concluded that total evacuation would be required in order to avoid starvation of the remaining population, but this advice was not heeded. ${ }^{1}$

Figure 1. Timeline showing major events during the occupation of Guernsey, $1940-45$.

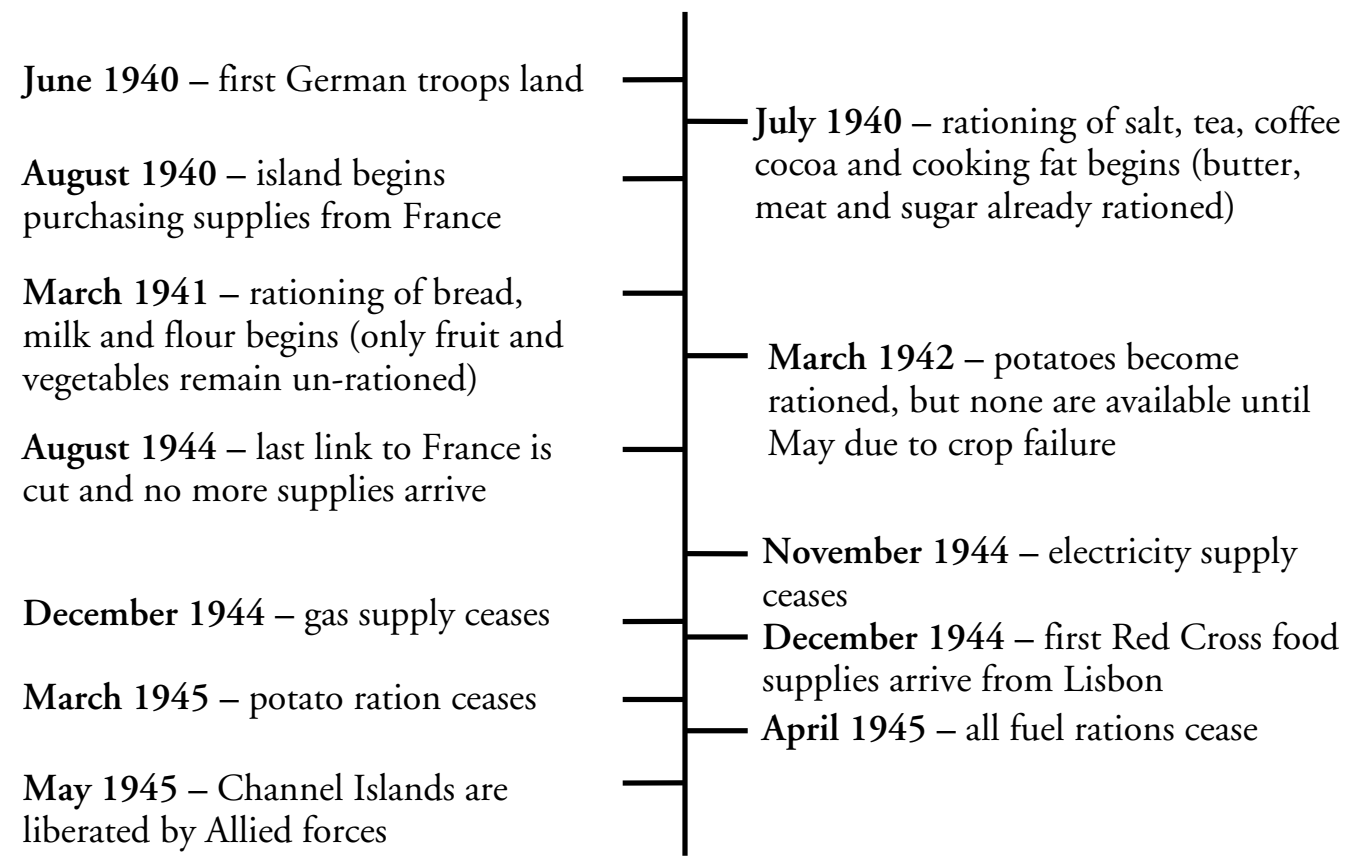

Source: Report on Essential Supplies and Services during the Occupation of Guernsey by German Forces and the Work of the Committee, States of Guernsey Committee for the Control of Essential Commodities.

At the beginning of the occupation, conditions were bearable on all of the islands, as large stocks of food and other essentials had been laid in from the beginning of the war. ${ }^{12}$ However, from 1941 onwards conditions became increasingly difficult as these stocks ran out and had to be replaced by whatever substitutes could be obtained from France - substitutes which were often of inadequate quantity and

8 Bunting (2004).

9 Bihet, M. (1985). A Child's War: The German Occupation of Guernsey as seen through young eyes. Sparkford: Haynes.

10 Sanders (2005).

11 Cruickshank, C. (1975). The German Occupation of the Channel Islands: The official history of the occupation years. Guernsey: Guernsey Press.

12 Sinel, L. (1958). Swastika Over Jersey: An outline of the occupation and the liberation of the island. Guernsey: Guernsey Press. 
inferior quality. Leslie Sinel in his 1958 book, Swastika Over Jersey: An Outline of the Occupation and the Liberation of the Island, stated that successive Christmases passed "each more grim than the one before" ${ }^{13}$ However, there is evidence that the winter of 1941-2 was particularly difficult owing to the failure of the potato crop. Indeed, RCF Maugham (1946: 97) pointed out that "[ $\mathrm{t}]$ he winter months [of 1941-2] brought with them a long period of domestic misery, owing to hunger and cold. Neither was easy to bear".

The situation became more severe for islanders in the summer of 1944, when the liberation of Normandy following the D-Day landings cut the islands off from mainland France. From this point onwards the islands were under siege and their meagre stocks of food did not last very long. By the end of that year the islands were on the brink of starvation, and were only reprieved by the arrival of food and other essential supplies from the Red Cross. A letter from an islander in autumn 1944, reproduced by Madeleine Bunting in the 2004 edition of her book, The Model Occupation, expressed the sentiment of the time: "Life is not worth living, we cannot sleep at nights, we are so worried and distressed... we are starving here". ${ }^{14}$ Even after the arrival of Red Cross supplies the islands continued to be in a desperate situation until the end of the war, since the German army increasingly requisitioned civilian food and materials in order to save themselves from starvation, ${ }^{15}$ on the grounds that the islanders were now being fed by the "protecting power" via the Red Cross.

There is evidence that the occupation did not affect all sections of society equally, despite the fact that food and other essentials were carefully rationed. A report drawn up by the President of the Guernsey Board of Health and cited by Madeleine Bunting (2004: 125) concluded that "the poor and the elderly, particularly in the towns, had suffered the worst". Times were particularly hard for families where the father had left to enlist in the British armed forces, because the reduced income made it difficult to obtain extra supplies on the black market. ${ }^{16}$ Likewise, women are thought to have suffered particularly badly, because they would give up their rations to feed their husbands and children. ${ }^{17}$

Charles Cruickshank (1975: 133) argued that "no two islanders were affected in exactly the same way by the occupation" - wealth was definitely important for mitigating the worst of the conditions, as was residence in one of the islands' rural parishes where more food could be grown and hidden. Farmers, in particular, are likely to have fared better because they were permitted to retain a proportion of their produce, and many secretly retained a great deal more than they were officially

13 Sinel (1958): 18.

14 Bunting (2004): 236.

15 Jeffs (1999).

16 Bunting (2004).

17 Sanders (2005). 
allowed. ${ }^{18}$ Indeed, some sections of the population may have escaped much of the occupation relatively unscathed. According to Paul Sanders' (2005) account, the Reverend Mylne in Jersey believed that some $10-15 \%$ of the population were essentially unharmed by the occupation either because they "made deals" with the Germans or because they were so affluent that they could secure additional food and other essentials regardless of black market prices. ${ }^{19}$ This figure may have been lower in Guernsey because of the harsher conditions there, but even there not everyone will have suffered equally. Nonetheless, it seems likely that most of the population suffered some ill effects from the occupation, and no-one appeared to have been unaffected by the worsening conditions precipitated by the 1944-45 siege.

\section{Rations and other sources of food}

At the beginning of the war, food stocks had been increased to full storage capacity, but rationing was quickly introduced in order to make the most of these stocks. ${ }^{20}$ At first the rations were adequate, but a new system soon had to be implemented, and in September 1940 the island authorities began to purchase supplies from France. However, the amount obtained was much less than that imported during peacetime. For example, the total quantity of food imported into Guernsey during 1938-39 amounted to $1 \mathrm{~kg}$ per person per day, while the average for the occupation years (excluding the period of the 1944-45 siege) was only $0.4 \mathrm{~kg}$ per person per day. ${ }^{21}$ As Sir Abraham Lainé mentions in the final report of Guernsey's Essential Commodities Committee, "The supplies of foodstuffs allocated to the island periodically by the French Authorities did not allow anything like an adequate standard of living to be maintained". 22

By August 1941, rationing extended to almost all foodstuffs and other essentials, including bread (see Tables 2 and 3). Fruit and vegetables were the only food freely available, but even these were in limited supply because they were only available seasonally and those that were imported often did not survive the journey from France intact. ${ }^{23}$ Indeed, even after the introduction of rationing, certain foods became increasingly difficult to obtain, so that by 1942 rations of pork and poultry

18 Lewis, J. (1983). A Doctor's Occupation: The dramatic true story of life in Nazi-occupied Jersey. Sevenoaks: New English Library.

19 Sanders (2005).

20 Lainé, A. (1945a). Occupation Diary. Guernsey: Island Archives Service.

21 Lainé (1945a).

22 Lainé (1945a):10.

23 Sanders (2005). 
Table 2. Weekly rations of major foodstuffs provided to adults in Guernsey during the occupation - certain categories such as heavy workers or hospital patients sometimes received slightly higher rations of some items.

\begin{tabular}{lcccccc}
\hline Week Beginning & Butter & Potatoes & Sugar & Meat & Milk(separated) & Salt \\
\hline $1^{\text {st }}$ July 1940 & $4 \mathrm{oz}^{1}$ & $\mathrm{NR}$ & $8 \mathrm{oz}$ & $2 /-1$ & $\mathrm{NR}$ & $1 \mathrm{oz}$ \\
$30^{\text {th }}$ Sept 1940 & $4 \mathrm{oz}$ & $\mathrm{NR}$ & $6 \mathrm{oz}$ & $1 /-$ & $\mathrm{NR}$ & $2 \mathrm{oz}$ \\
$31^{\text {st }}$ March 1941 & $4 \mathrm{oz}$ & $\mathrm{NR}$ & $6 \mathrm{oz}$ & $1 /-$ & $31 / 2 \mathrm{pt}^{1}$ & $2 \mathrm{oz}$ \\
$29^{\text {th }}$ Sept 1941 & $4 \mathrm{oz}$ & $\mathrm{NR}$ & $3 \mathrm{oz}$ & $6 \mathrm{oz}$ & $31 / 2 \mathrm{pt}$ & $3 \mathrm{oz}$ \\
$23^{\text {rd }}$ March 1942 & $4 \mathrm{oz}$ & $\mathrm{Nil}$ & $\mathrm{Nil}$ & $4 \mathrm{oz}$ & $31 / 2 \mathrm{pt}$ & $3 \mathrm{oz}$ \\
$28^{\text {th }}$ Sept 1942 & $4 \mathrm{oz}$ & $5 \mathrm{lb} 1$ & $3 \mathrm{oz}$ & $4 \mathrm{oz}$ & $31 / 2 \mathrm{pt}$ & $2 \mathrm{oz}$ \\
$29^{\text {th }}$ March 1943 & $4 \mathrm{oz}$ & $5 \mathrm{lb}$ & $3 \mathrm{oz}$ & $4 \mathrm{oz}$ & $31 / 2 \mathrm{pt}$ & $\mathrm{Nil}$ \\
$27^{\text {th }}$ Sept 1943 & $4 \mathrm{oz}$ & $5 \mathrm{lb}$ & $3 \mathrm{oz}$ & $6 \mathrm{oz}$ & $31 / 2 \mathrm{pt}$ & $1 \mathrm{oz}$ \\
$27^{\text {th }}$ March 1944 & $3 \mathrm{oz}$ & $\mathrm{Nil}$ & $3 \mathrm{oz}$ & $4 \mathrm{oz}$ & $31 / 2 \mathrm{pt}$ & $1 \mathrm{oz}$ \\
$25^{\text {th }}$ Sept 1944 & $4 \mathrm{oz}$ & $6 \mathrm{lb}$ & $2 \mathrm{oz}$ & $\mathrm{Nil}$ & $51 / 4 \mathrm{pt}$ & $\mathrm{Nil}$ \\
$26^{\text {th }}$ March 1945 & $\mathrm{Nil}$ & Nil & Nil & Nil & $1 / 2 \mathrm{pt}$ & $4 \mathrm{oz}$
\end{tabular}

${ }^{1}$ Units: oz - ounces $(1 \mathrm{oz}=28 \mathrm{~g}) ; \mathrm{lb}-$ pounds $(1 \mathrm{lb}=454 \mathrm{~g}) ; \mathrm{pt}-$ pints $(1 \mathrm{pt}=568 \mathrm{ml})$

Source: Report on Essential Supplies and Services during the Occupation of Guernsey by German Forces and the Work of the Committee, States of Guernsey Committee for the Control of Essential Commodities.

had disappeared completely and fish was a rare luxury due to restrictions on fishing. ${ }^{24}$ Rations were substantially reduced in quantity towards the end of 1941 (see Tables 2 and 3), and from this point onwards only skimmed milk was available in Guernsey, although Jersey had access to full cream milk for the duration of the occupation. ${ }^{25}$ The poor potato harvest in $1941 \mathrm{did}$ not help matters ${ }^{26}$ and by 1943 the potato ration had been drastically reduced, while the potatoes that were available were of very low quality, half being rotten. ${ }^{27}$ The rations were completely inadequate by 1944 , so that most meals consisted of vegetable soup and meat was only provided once every two weeks. ${ }^{28}$

Finally, during the 1944-45 siege, the rations available could not provide enough for people to survive. By this point they were a quarter of the level of German rations, ${ }^{29}$ and required supplementation from off-ration foodstuffs. Indeed, estimates from the occupation indicate that the rations in Jersey provided just 2100$2500 \mathrm{kcal}$ per day (i.e. $70-83 \%$ of an estimated average adult requirement of 3000 kcal per day) up until $1944,{ }^{30}$ and that by the end of 1944 this had fallen to

24 Bihet, M. (1993). Reflections of Guernsey, Guernsey: Guernsey Press; Sanders (2005).

25 Lewis (1983).

26 Cruickshank (1975).

27 Lainé (1945a)

28 Lainé (1945a).

29 Bunting (2004).

30 Sanders (2005). 
Table 3. Weekly bread ration provided in Guernsey during the occupation.

\begin{tabular}{|c|c|c|c|c|c|c|}
\hline Week Beginning & $\begin{array}{l}\text { Male } \\
\text { heavy } \\
\text { worker }\end{array}$ & $\begin{array}{l}\text { Other } \\
\text { male } \\
\text { adult }\end{array}$ & $\begin{array}{l}\text { Female } \\
\text { heavy } \\
\text { worker }\end{array}$ & $\begin{array}{l}\text { Other } \\
\text { female } \\
\text { adult }\end{array}$ & $\begin{array}{l}\text { Children } \\
\text { over } 11 / 2\end{array}$ & $\begin{array}{l}\text { Children } \\
\text { under } 11 / 2\end{array}$ \\
\hline $24^{\text {th }}$ Mar 1941 & $6 \mathrm{lb} 2 \frac{1}{2} 2 \mathrm{oz}^{1}$ & $41 \mathrm{lb} 10 \mathrm{oz}$ & $5 \mathrm{lb} 61 / 4 \mathrm{Oz}$ & $4 \mathrm{lb} 10 \mathrm{oz}$ & $3 \mathrm{lb} 11 / 2 \mathrm{Oz}$ & $3 \mathrm{lb} 1 \frac{1}{2} \mathrm{Oz}$ \\
\hline $28^{\text {th }}$ July 1941 & $6 \mathrm{lb} 2 \frac{1}{1} 2 \mathrm{Oz}$ & $4 \mathrm{lb} 10 \mathrm{oz}$ & $5 \mathrm{lb} 61 / 4 \mathrm{Oz}$ & $4 \mathrm{lb} 10 \mathrm{oz}$ & $3 \mathrm{lb} 1 \frac{1}{2} 2 \mathrm{Oz}$ & $1 \mathrm{lb} 8 \mathrm{oz}$ \\
\hline $15^{\text {th }}$ Sep 1941 & $6 \mathrm{lb} 0 \mathrm{oz}$ & $4 \mathrm{lb} 8 \mathrm{oz}$ & $5 \mathrm{lb} 4 \mathrm{oz}$ & $41 \mathrm{~b} 8 \mathrm{oz}$ & $31 \mathrm{~b} 0 \mathrm{oz}$ & $1 \mathrm{lb} 8 \mathrm{oz}$ \\
\hline $10^{\text {th }}$ May 1943 & $41 \mathrm{lb} 12 \mathrm{oz}$ & $3 \mathrm{lb} 12 \mathrm{oz}$ & $4 \mathrm{lb} 4 \mathrm{oz}$ & $3 \mathrm{lb} 12 \mathrm{oz}$ & $3 \mathrm{lb} 0 \mathrm{oz}$ & $1 \mathrm{lb} 8 \mathrm{oz}$ \\
\hline $1^{\text {st }}$ Aug 1943 & $6 \mathrm{lb} 0 \mathrm{oz}$ & $4 \mathrm{lb} 8 \mathrm{oz}$ & $5 \mathrm{lb} 4 \mathrm{oz}$ & $4 \mathrm{lb} 8 \mathrm{oz}$ & $3 \mathrm{lb} 0 \mathrm{oz}$ & $1 \mathrm{lb} 8 \mathrm{oz}$ \\
\hline $27^{\text {th }}$ Nov 1944 & $3 \mathrm{lb} 0 \mathrm{oz}$ & $3 \mathrm{lb} 0 \mathrm{oz}$ & $3 \mathrm{lb} 0 \mathrm{oz}$ & $3 \mathrm{lb} 0 \mathrm{oz}$ & $3 \mathrm{lb} 0 \mathrm{oz}$ & $1 \mathrm{lb} 8 \mathrm{oz}$ \\
\hline $12^{\text {th }}$ Mar 1945 & $5 \mathrm{lb} 0 \mathrm{oz}$ & $5 \mathrm{lb} 0 \mathrm{oz}$ & $5 \mathrm{lb} 0 \mathrm{oz}$ & $5 \mathrm{lb} 0 \mathrm{oz}$ & $41 \mathrm{~b} 0 \mathrm{oz}$ & $1 \mathrm{lb} 0 \mathrm{oz}$ \\
\hline
\end{tabular}

${ }^{1}$ Units: oz - ounces $(1 \mathrm{oz}=28 \mathrm{~g}) ; \mathrm{lb}-$ pounds $(1 \mathrm{lb}=454 \mathrm{~g})$

Source: Report on Essential Supplies and Services during the Occupation of Guernsey by German Forces and the Work of the Committee, States of Guernsey Committee for the Control of Essential Commodities.

$2000 \mathrm{kcal}$ per day, or as low as $1700 \mathrm{kcal}$ per day for working class families. ${ }^{31}$ The Medical Officer in Guernsey believed that caloric intake did not fall below 2300 kcal per day during this period, but when a medical team visited Guernsey after the liberation in 1945, the diet was found to be poorer than that of Jersey. ${ }^{32}$ More recent estimates indicate that the daily ration in Guernsey during the winter and spring of 1942 was equivalent to $1198 \mathrm{kcal}$ per day, and in the last 10 months of the occupation had fallen to just $1163 \mathrm{kcal}$ per day. Both of these amounts offer less than half of the estimated average adult requirements, but their impact would have been worst during 1944-45 when off-ration foods were largely unavailable. ${ }^{33}$

It appears clear, then, that the population of the Channel Islands would have needed to rely on sources of off-ration food to supplement their meagre rations. The largest alternative source of off-ration food was the black market, which was in full operation from early in the occupation and in which virtually the entire population of the Channel Islands seems to have participated. ${ }^{34}$ An extract from a letter from Guernsey resident Richard Foley to his mother during the occupation (reproduced in the 1995 memories of the Guernsey Women's Institute) suggested that: "Almost everybody in the island managed somehow or other to get things apart from the basic rations, as on these alone I do not see how any of us could possibly

31 Cruickshank (1975).

32 Cruickshank (1975).

33 Langlois, A. (1999). Undernutrition in Early Life and Cause of Premature Mortality in Guernsey. Cambridge: Hons. Thesis, Department of Biological Anthropology, University of Cambridge.

34 Maugham, R. C. F. (1946). Jersey under the Jackboot: A first-hand account of the island's ordeal during the German occupation. London: W. H. Allen and Co. 
have survived". ${ }^{35}$ Many people appear to have spent their life savings on the black market, ${ }^{36}$ as prices became increasingly prohibitive with increasing scarcity. Although officially forbidden by the Germans, there was also a barter market through the shops and in the press, so that those with a little surplus of basic essentials could exchange this with others. ${ }^{37}$

As a supplement to official rations and food acquired through the black market, islanders also became experts at foraging and creating food from unlikely sources. These methods ranged from eking out foodstuffs by, for example, eating potato peelings and food that had gone bad, ${ }^{38}$ to the production of salt, magnesium carbonate and fish oils in a specially constructed plant to help provide some of the nutrients islanders were missing in their diet. ${ }^{39}$ People discovered how to make puddings from carrageen moss (a local seaweed) and skimmed milk, ${ }^{40}$ while the only sources of fat and sugar were the small quantities of buttermilk which were provided from time to time. ${ }^{41}$ Less palatable additions to the diet provided by foraging included maggots and husks. ${ }^{42}$ Worse, by 1943 most bread was a mixture of wheat, oats, peas and mashed potato, as well as sweepings from the floors of bakeries, none of which is likely to have aided the digestion of islanders. ${ }^{43}$

Finally, it is clear that some islanders were reduced to stealing from one another, although this is thought to have been rare. Cases of theft, while common, were thought to be mostly committed by the foreign forced labourers brought to the islands by the Germans, many of whom were already on the brink of starvation when they arrived. Additionally, German troops routinely used their position of power to "requisition" islanders' food, even when this was against the law. ${ }^{44}$ However, members of Guernsey's police force were also tried for the theft of food from civilian stores during the occupation. In their defence they stated that their rations and pay were inadequate, PC Kingston Bell being quoted as saying, "It became obvious that the rich could live and the poor could starve". ${ }^{45}$ It is therefore hardly surprising that some islanders were reduced to breaking the law.

35 Dales, G. (1995). "True account of relatives under German Occupation in Guernsey in the year 1944”, Careless Talk Costs Lives: Memories 1939-1945. Guernsey: Guernsey Women's Institute: 36.

36 Day, O. (1995). "Extracts from a letter sent by Richard Foley to his mother 12th June 1945”, Careless Talk Costs Lives: Memories 1939-1945. Guernsey: Guernsey Women's Institute.

37 Cruickshank (1975).

38 Sanders (2005).

39 Lainé (1945a).

40 Lainé (1945a).

41 Bihet (1985).

42 Bihet (1985).

43 Lewis (1983).

44 Cruickshank (1975).

45 Bell, W. M. (1995). I Beg to Report. Policing in Guernsey During the German Occupation. Guernsey: Guernsey Press: 183. 


\section{Conditions during the siege}

The final ten months of the war were undoubtedly the worst period of the occupation for the Channel Islands. Following the D-Day landings in June 1944 conditions on the islands began to deteriorate until, by August 1944, no supplies could get to the islands from mainland France. ${ }^{46}$ At this point there was nothing left to buy in the shops, and civilian rations were reduced to bare subsistence levels, ${ }^{47}$ with off-ration foodstuffs being unavailable even on the black market. ${ }^{48}$ Evidence obtained by the British government in the autumn of 1944 suggested that the standard of living among the civilian population of the Channel Islands was very poor, and that "the people, especially the less well-off, were near breaking point". ${ }^{4}$

Living conditions continued to deteriorate as the weather grew colder during the winter of 1944-45 - so much so that, in her Jersey occupation diary, Nan Le Ruez (1994: 249) stated that there was "misery" in the town, and that people were particularly suffering from lack of fuel, so that even had they obtained more food, they could not have cooked it. During this winter, according to Alan and Mary Wood (1955: 196), "life became completely primitive", with people going to bed after lunch because there was nothing more to eat and they needed to save energy. Likewise, Beryl Ozanne (1994: 118), a nurse in Guernsey throughout the war, felt that by this stage of the occupation, the rations "hardly kept body and soul together". Indeed, in his history of the occupation, Charles Cruickshank (1975: 141) argued that "By and large the health pluses and minuses balanced out during the greater part of the occupation, but in the two or three months [of 1944] before the Red Cross supplies began to arrive there was a real threat of general starvation".

The situation was alleviated somewhat by the arrival of the Red Cross ship Vega at the end of December 1944, by which point many Channel Islanders were indeed facing starvation. ${ }^{50}$ This is evident from an article published in the Jersey Evening Post at the time which made it clear that "only those who have knowledge of how many of the poorer inhabitants have lived during the past months can imagine what this will mean". ${ }^{51}$ Certainly, it seems likely that the arrival of the Vega saved many lives ${ }^{52}$ and many believed that the arrival of the Red Cross parcels saved the

46 Bell (1995); Sanders (2005).

47 Cruickshank (1975); Le Ruez, N. (1994). Jersey Occupation Diary. Jersey: Seaflower Books.

48 Sinel, L. (1984). The German Occupation of Jersey: The complete diary of events from June 1940 to June 1945. Jersey: La Haule.

49 Cruickshank (1975): 269.

50 Bihet (1985); Sinel (1958).

51 Sinel (1958): 29.

52 Bihet (1985); Mayne, R. (1945). Operation "Nestegg": The liberation of Jersey 1945. Jersey: Channel Printers. 
population as a whole from starvation. ${ }^{53}$ Indeed, when the extra supplies arrived, there were tales of people making themselves ill because they were no longer used to adequate quantities of food. ${ }^{54}$ Elsewhere, there was such demand for the extra food that people were often robbed for their parcels, and at least one couple was murdered by German soldiers for this food. ${ }^{55}$

Nonetheless, even with the arrival of emergency food supplies, the situation in the Channel Islands remained critical until the end of the war. For example, the bread ration ran out in February 1945, so that islanders had to cope for several weeks without one of their staple foods. ${ }^{56}$ By this point there were also problems with the potato and milk rations, so that islanders often had virtually nothing to live on. ${ }^{57}$ Communal cooking had been instituted in Guernsey in December 1944, followed by the opening of soup kitchens, but these had to be stopped in March 1945 because there were not enough rations to keep them going. ${ }^{58}$ These conditions were not to improve until hostilities ceased in May 1945, when a sudden influx of supplies brought conditions very quickly back to almost normal levels.

\section{Fuel and medical supplies}

While the food situation was undoubtedly very serious, particularly during the 1944-45 siege, additional problems were caused by a lack of other essential supplies, such as fuel for heating and cooking, and medical supplies. Fuel was rationed from quite early on in the occupation, so that in Jersey there was often no electricity even during the first winter. ${ }^{59}$ Heating of rooms by coal and gas was forbidden from spring 1941 onwards, as was the use of electricity for anything other than lighting. By that summer it was also forbidden to heat water using gas. ${ }^{60}$ There was a shortage of candles, and the felling of trees was prohibited, so that even a log fire was hard to come by. In A Century of Jersey Memories, Sonia Hillsdon (1999: 12) recorded that "Food was short during the Occupation but, for the poor housewife, the means to cook it was almost as difficult to cope with."

53 Ozanne, B. S. (1994). A Peep Behind the Screens: 1940-1945. Guernsey: Guernsey Press.

54 Ozanne (1994).

55 Dales (1995).

56 Dales (1995); Sinel (1984).

57 Maugham (1946).

58 Lainé (1945).

59 Lewis (1983).

60 Maugham (1946). 
By the end of the occupation people were dismantling empty houses and burning the timber for fuel, and were even using sawdust stoves for cooking. ${ }^{61}$ In Jersey the gas supply was completely cut off in the summer of 1944, while electricity was only on for 2 to 3 hours per day, and even this was eventually cut off completely. ${ }^{62}$ The situation was similar in Guernsey, where gas supplies ceased in November 1944 and electricity supplies in December of $1944 .^{63}$ By this point communal kitchens were the only source of hot food ${ }^{64}$ and many public buildings such as schools had to close because there was no way of heating them. Paul Sanders, in his history of the occupation, argued that the lack of cooking and heating facilities was almost as serious as the lack of food in terms of the health and morale of the population. ${ }^{65}$

Medical supplies and facilities were also a serious problem. Many doctors had evacuated from the islands before the occupation began, ${ }^{66}$ and the shortage of fuel meant that ambulances often could not run. Eventually a horse-drawn ambulance was the only method of getting emergency cases to hospital. ${ }^{67}$ Meanwhile, the German army took over many of the islands' medical buildings, leaving less than adequate facilities for the civilian population. Medical care at these facilities tended to be extremely basic, often with no electricity and no sterile dressings or gloves. ${ }^{68}$ Hospital staff often had problems completing their shifts due to exhaustion, ${ }^{69}$ which is not surprising given that at one stage the daily ration for nurses in Guernsey only comprised a cup of acorn coffee and some turnip stew. ${ }^{70}$ According to the first-hand account of one Guernsey nurse, ${ }^{71}$ some hospital staff were also weakened by dysentery and found it more and more difficult to perform their duties. Likewise, their patients were also undernourished while in hospital, ${ }^{72}$ and this tended to prolong their recovery, placing further pressure on the meagre resources available. ${ }^{73}$

There was also a shortage of drugs and other medical supplies from quite early in the occupation, despite periodic deliveries from the Red Cross between 1941 and 1944 - deliveries which included insulin, vitamin C and serum for diphtheria and

61 Hillsdon, S. (ed.) (1999). A Century of Jersey Memories. Bradford on Avon: Seaflower Books; Sinel (1984).

62 Lewis (1983).

63 Sanders (2005).

64 Sinel (1984).

65 Sanders (2005).

66 Lewis (1983).

67 Lewis (1983).

68 Lewis (1983).

69 Lainé (1945).

70 Wood, A., Wood, M. (1955). Islands in Danger. London: Wyman and Sons.

71 Ozanne (1994).

72 Bell (1995).

73 Ozanne (1994). 
morphine, as well as dressings and scalpels. ${ }^{74}$ Before the siege, some medicines could be imported from France, although these tended to be of poor quality and sometimes did not work. ${ }^{75}$ The islands also produced their own improvised tonics and remedies to replace those no longer available, and these helped to eke out supplies until $1944 .^{76}$ However, towards the end of 1944 there were few supplies left, and only the most essential operations could be performed, ${ }^{77}$ in particular due to a shortage of catgut for stitching. ${ }^{78}$ The absence of drugs became very serious, especially for diabetics when there was no more insulin, and many of these patients died. ${ }^{79}$ It was no longer possible to vaccinate people against many diseases, and this may have contributed to an increase in several common diseases during the occupation. ${ }^{80}$ Indeed, in addition to the problems caused by the reduced medical supplies, there was also an increased demand for medical care, not least because a number of illnesses increased due to the poor $\operatorname{diet}^{81}$ so that the islanders may have suffered more than would have been the case due to a lack of food alone.

\section{Hygiene}

Poor hygiene was an additional problem faced by Channel Islanders during the occupation, and one that could have become much more serious had the war not ended when it did. By September 1943 there was no mains water supply between $7 \mathrm{pm}$ and $7 \mathrm{am},{ }^{82}$ and by the end of the occupation these hours had been further curtailed. This was exacerbated by low rainfall during the occupation years - a serious problem for islands dependent on rainfall for their water supply. ${ }^{83}$ In March 1945 all houses were limited to one tap, all flush toilets were disconnected, and water was only available from the remaining tap for just three hours per day. ${ }^{84}$ This is likely to have led to severe problems with disease had the islands not been liberated three months later.

As well as a lack of water for washing, there was also a lack of soap, which further increased the danger of disease and infection. At the beginning of the occupation people were instructed to wash their hands only once a day to conserve soap, but

74 Lainé (1945a).

75 Lewis (1983).

76 Rivett, P. J. (2001). A Tiny Act of Defiance. Paignton: Planetesimal; Sanders (2005).

77 Bell (1995).

78 Sanders (2005).

79 Lewis (1983).

80 Lainé (1945a).

81 Rivett (2001).

82 Sinel (1984).

83 Lainé (1945a).

84 Lainé (1945b). 
even this precaution did not prevent soap supplies running out. ${ }^{85}$ Indeed, the English soap previously used by islanders ran out by June 1941 apart from a small reserve set aside for use in maternity cases. ${ }^{86}$ Thereafter, the soap obtained from France tended to be of very poor quality. By October 1944, adults had not received any soap for three months, ${ }^{87}$ and the islands only received a proper supply again with the arrival of the Vega in December 1944.

The lack of proper hygiene precipitated by inadequate supplies of water and soap resulted in an increased prevalence of skin infections and ulcers, ${ }^{88}$ and when the toothpaste ran out there was also an increase in tooth and gum problems. ${ }^{89}$ Lice infestations became common because even when there was water it was rarely possible to heat it. ${ }^{90}$ Added to the islanders' nutritionally compromised immune systems, poor hygiene became a potentially serious problem towards the end of the occupation as people were not able to fight off infections as effectively as they would under normal circumstances.

\section{Health and disease}

Despite the reports summarised above, in the main, the general health impact of the occupation was perhaps not as bad as it might have been. Indeed, in some respects health actually improved, such as the weight loss that benefited the obese, ${ }^{91}$ especially in terms of cardiac health. ${ }^{92}$ In some cases this might have also helped some previously overweight women to conceive, ${ }^{93}$ while even those women who appeared to have become underweight as a result of the occupation still seemed to give birth to healthy sized babies. ${ }^{94}$ One Jersey doctor stated that, particularly in the early days of rationing, his more overweight patients benefitted from their change of diet. ${ }^{95}$ Elsewhere, the health of the population of Guernsey was thought to be "exceptionally good" during the first winter of the occupation. Some aspects of

85 Lainé (1945b).

86 Lainé (1945b).

87 Sinel (1984).

88 Wood and Wood (1955).

89 Lewis (1983).

90 Lewis (1983).

91 Cruickshank (1975).

92 Sanders (2005).

93 Rivett (2001).

94 Lewis (1983).

95 McLoughlin, R. (1995). Living With the Enemy: An outline of the German occupation of the Channel Islands with first-hand accounts by the people who remember the years 1940 to 1945 . St Helier: Starlight.

96 Lainé (1945b). 
the occupation diet that may have been advantageous in this regard were the reduced sugar and fat content, and the increased consumption of wholemeal flour.

However, the weight loss experienced by most Channel Islanders during the occupation was not beneficial to all sectors of the population, such as the elderly and infirm and those who were required to do physical work. For example, the outdoor telephone staff in Guernsey each lost an average of $22 \mathrm{lbs}(10 \mathrm{~kg})$ in weight between 1940 and 1943, and the associated loss of energy began to prevent them from doing their jobs properly even before the onset of the siege in $1944{ }^{98}$ Even the Jersey doctor cited earlier, who was wealthy and had many contacts from whom to obtain off-ration food, saw his body weight fall from 13 stone $(83 \mathrm{~kg})$ to under 9 stone $(57 \mathrm{~kg})$ by the end of the war. ${ }^{99}$ Indeed, he stated that many of his patients experienced similar losses, including his mother-in-law, who weighed less than 6 stone $(38 \mathrm{~kg})$ by the end of the occupation. Some elderly people seem to have ended the war at an alarmingly low weight, as evidenced by an inquest into the death of a 70-year-old Jersey woman where "malnutrition" was cited as a secondary cause, and whose weight was reported to be only 3 stone $(19 \mathrm{~kg}){ }^{100}$

Some of the islanders in prominent positions also appeared to have suffered disproportionately, as a result of the fact that it would not have been proper for them to have been seen to be indulging in the black market. As a consequence, the Dame of Sark lost 4 stone $(25 \mathrm{~kg})$ in weight during the occupation, and towards the end of the siege weighed only 7 stone $(44 \mathrm{~kg}) .{ }^{101}$ The Bailiffs of Jersey and Guernsey were in a similar predicament, with Alexander Coutanche, Bailiff of Jersey, losing over 2 stone (13kg), and Victor Carey, Bailiff of Guernsey, losing 5 stone $(32 \mathrm{~kg})$ during the occupation. ${ }^{102}$ Likewise, the Rector of St Helier, who took a principled stand against the black market, lost half his body weight as a result. ${ }^{103}$

The most extreme example of weight loss cited by any source was the case of a Guernsey man whose weight dropped from 18 stone $(115 \mathrm{~kg})$ to 8 stone $(51 \mathrm{~kg})$ by the end of the war. ${ }^{104}$ Not surprisingly, Adèle Lainé described in her Occupation Diary how, by the end of the siege, people in Guernsey were often unrecognisable because they had lost so much weight. ${ }^{105}$ Likewise, Leslie Sinel recorded in his diary

97 Jeffs, D. (ed.) (1999). One Hundred Years of Health: The changing health of Guernsey 1899-1999. Guernsey: Board of Health.

98 Cruickshank (1975).

99 Lewis (1983).

100 Sinel (1984).

101 Tabb, P. (2005). A Peculiar Occupation: New Perspectives on Hitler's Channel Islands. Hersham: Ian Allan.

102 Wood and Wood (1955).

103 Sanders (2005).

104 Rivett (2001).

105 Lainé (1945a). 
that by June 1942 some islanders had "lost weight to an astounding degree". ${ }^{106}$ In his history of the occupation of Jersey, RCF Maugham mentioned that in 1943 the general public began to look emaciated, and that by the end of the war, "[t]he people grew thin, their features pinched by privation and want... [n]ormal strength and vitality could just not be maintained".

Although this weight loss must have been alarming, it seems to have been malnutrition that affected the islands most as opposed to outright starvation ${ }^{108}$ since the principal problem lay with the composition of the diet rather than a paucity of calories, at least until the onset of the siege. ${ }^{109}$ When the islands were starving, towards the end of the siege, this took the form of slow starvation rather than acute deprivation. This may have made the crucial difference between suffering and death for many, ${ }^{110}$ since the Channel Islanders were able to become gradually accustomed to fewer and fewer calories rather than being suddenly deprived. However, this is not to say that the effects of this 'creeping malnutrition' were not serious, as malnutrition was recorded as a cause of death on a number of death certificates at the time. ${ }^{111}$ Malnutrition also caused loss of memory, concentration and stamina, and many people collapsed in the street as they were going about their daily tasks. There were cases of famine oedema of the legs, again particularly among the elderly, ${ }^{112}$ while recovery rates from a number of other conditions were notably slow.

Increases in several other diseases and illnesses were also reported during the occupation, including tuberculosis, ${ }^{113}$ scarlet fever, ${ }^{114}$ dysentery, ${ }^{115}$ tetanus, ${ }^{116}$ typhoid, ${ }^{117}$ hepatitis, ${ }^{118}$ jaundice, ${ }^{119}$ chicken pox ${ }^{120}$ and whooping cough ${ }^{121}$, as well as conditions such as diarrhoea ${ }^{122}$ and intestinal worms. ${ }^{123}$ Many people had sore gums and loose teeth, and there was speculation that this might be due to scurvy. ${ }^{124}$ There

106 Sinel (1984).

107 Maugham (1946).

108 Wood and Wood (1955); Ozanne (1994).

109 Sanders (2005).

110 Lainé (1945a); Lainé (1945b); Sanders (2005).

111 Cruickshank (1975), Lainé (1945b ); Sinel (1984).

112 Cruickshank (1975); Lewis (1983); Wood and Wood (1955).

113 Anquetil, A. F. (1990). Wartime Memories. Guernsey Archives Service: Guernsey; Sanders (2005); Jeffs (1999); Le Ruez (1994); Lewis (1983); Maugham (1946).

114 Sanders (2005); Sinel (1984).

115 Cruickshank (1975); Ozanne (1994).

116 Le Ruez (1994).

117 Jeffs (1999).

118 Lewis (1983).

119 Maugham (1946).

120 Tabb (2005).

121 Lewis (1983); Sanders (2005).

122 Cruickshank (1975); Lewis (1983); Sanders (2005).

123 Lewis (1983).

124 Lewis (1983). 
was also an epidemic of colic, perhaps as a result of people being encouraged to eat nettles, sorrel and bracken to supplement their diet. ${ }^{125}$ The cold did not help matters, and chilblains were prevalent and painful. ${ }^{126}$

Matters were said to have been particularly bad during the winters, and the islands' authorities tried to build up people's health during the summer months in order to maximise their chances of surviving until the following spring. ${ }^{127}$ When there was an outbreak of diphtheria in Jersey in 1944 this affected more adults than usual, ${ }^{128}$ and also affected many children because the immunisation programme had had to be stopped. ${ }^{129}$ Meanwhile, the German troops brought a range of diseases with them from the front, including trench mouth (a severe gum infection), mite infestations, syphilis and gonorrhoea. ${ }^{130}$ Colds and sore throats, however, were less common, perhaps because of reduced population movement both into and within the islands. ${ }^{131}$

There is some speculation as to whether the death rate increased during the years of the occupation. There is certainly some evidence that people died from malnutrition, including one death of an adult male on Jersey in September 1941 where the cause of death was listed as heart failure due to malnutrition. ${ }^{132}$ Many more such cases had been reported by $1945 .{ }^{133}$ The lack of proper medical supplies is also likely to have contributed to mortality rates, ${ }^{134}$ such as the lack of insulin which led to the deaths of most of the diabetics on the islands. ${ }^{135}$ From 1942 onwards there were reports of increasing numbers of deaths attributed to living conditions on the islands, although generally the precise cause of these was not specified. ${ }^{136}$ For example, Paul Sanders mentions an increase in the death rate in his history of the occupation, but states that this was not due to general starvation, but involved certain groups of the population such as the elderly, the young, members of large families and those with low incomes. ${ }^{137}$ Indeed, in Jersey the pre-war death rate was $12-13$ per 1000 , while by January 1945 this had risen to 35.6 per $1000 .{ }^{138}$ The death rate in Guernsey also rose at certain points during the occupation (see Figure 2), but these

125 Maugham (1946).

126 Lewis (1983); Sinel (1984).

127 Rivett (2001).

128 Cruickshank (1975); Lewis (1983); Maugham (1946); Sanders (2005); Sinel (1984).

129 Jeffs (1999); Lewis (1983).

130 Lewis (1983).

131 Cruickshank (1975); Rivett (2001); Sanders (2005).

132 Sinel (1984).

133 Bunting (2004); Lainé (1945b).

134 Ozanne (1994).

135 Lewis (1983).

136 Sinel(1984).

137 Bunting (2004); McLoughlin (1995); Sanders (2005).

138 Maugham (1946). 
increases were only found to be significant among the over-65 age group. ${ }^{139}$ Nonetheless, there were many deaths recorded as being due to "syncope", or sudden collapse from hunger. ${ }^{14}$

Figure 2. Mortality rates (per thousand population) in Guernsey during the occupation.

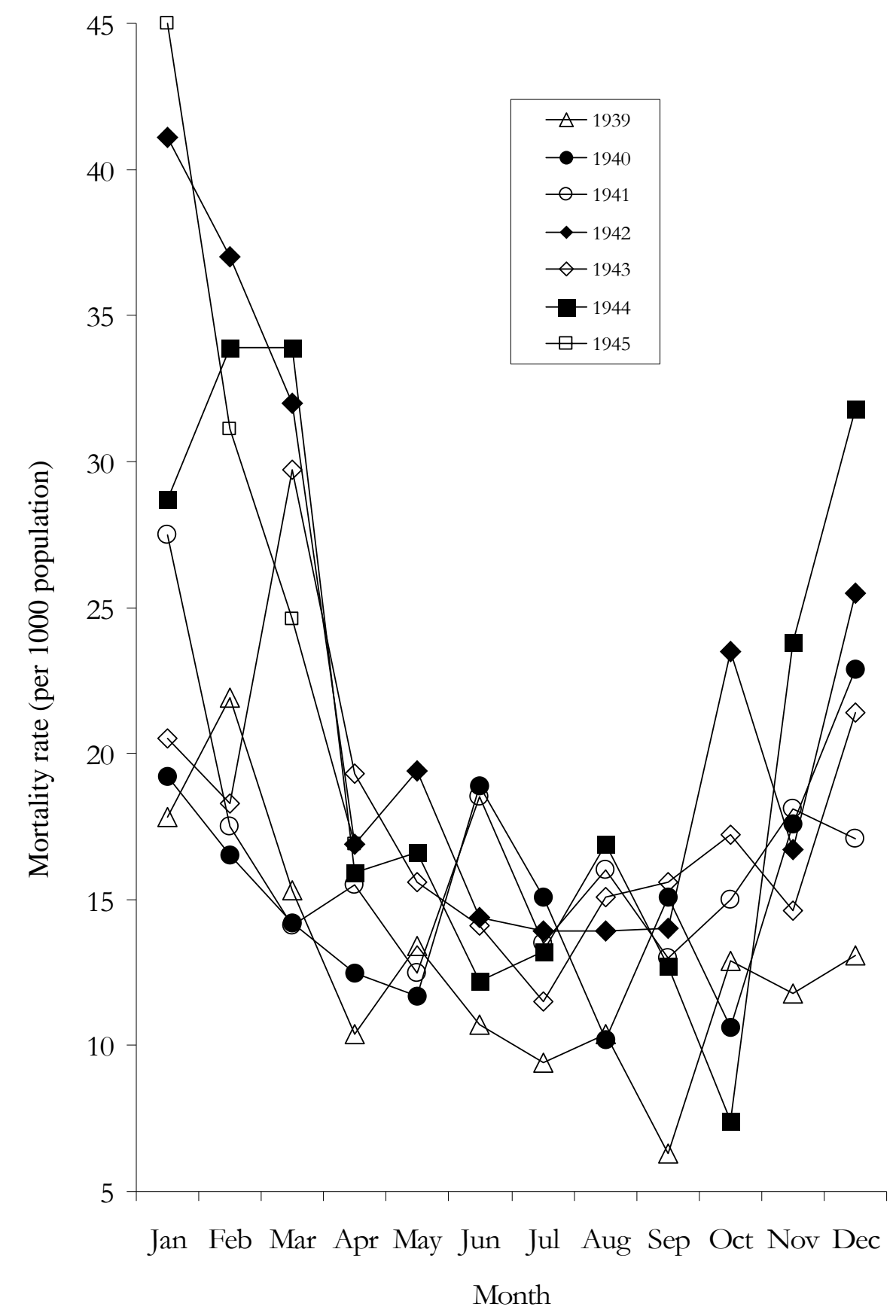

Source: Report on Essential Supplies and Services during the Occupation of Guernsey by German Forces and the Work of the Committee, States of Guernsey Committee for the Control of Essential Commodities.

139 Sanders (2005).

140 Maugham (1946). 


\section{Children and young people}

Children were allocated additional rations as they were perceived to be a particularly at-risk group. These included milk provided at school ${ }^{141}$ and sometimes soup, ${ }^{142}$ as well as the occasional orange ${ }^{143}$ and supplements of cod liver oil. ${ }^{144}$ The youngest children were also first in line to receive a ration of sugar whenever this became available. ${ }^{145}$ In fact, children under the age of 4 received twice as much sugar as adults, while children at school from time to time received biscuits from the 'Secours National' - a political and religious organisation which helped victims of the war. ${ }^{146}$ It may have been just as well that these extra rations were provided, since by the end of the occupation there was evidence that some children were eating very little apart from what they were given at school. ${ }^{147}$

Indeed, despite these additional rations there were numerous accounts of children, and teenagers in particular, faring particularly badly during the occupation. ${ }^{148}$ Teenagers did not receive the extra milk ration once they had left school, even though they needed plenty of extra energy to grow, not least if they were also engaged in manual labour, as many of them were. ${ }^{149}$ The British Nutrition Foundation (BNF) states that teenagers aged 15-18 actually require more calories per day than adults (see Table 4), and as such this group would have received proportionately fewer of the calories they required during the $1940-45$ occupation. ${ }^{150}$ Moreover, when German medical advisors examined the islanders they concluded that the rations available were adequate for all except, perhaps, children aged 6 to 14, whose needs were felt to be greater than the rations provided. ${ }^{151}$ This concurred with the views of a local doctor, who felt that children under 6 were adequately nourished but that older children suffered from inadequate food. ${ }^{152}$ It is therefore possible that these children actually suffered more than adults during the occupation. They were certainly hungry, as this letter to Father Christmas from a Guernsey child in 1940 testifies: "Could you bring me some chocolate? I have not

141 Bihet (1985); Langlois (1999); Leale, J. (1940-1945). Minutes of the Controlling Committee of the States of Guernsey. Guernsey; Lewis (1983); Sanders (2005).

142 Bihet (1985); Sinel (1984).

143 Lewis (1983).

144 Bihet (1985); Rivett (2001).

145 Sinel (1984).

146 Lainé (1945a).

147 Lainé (1945a).

148 Day (1995).

149 Day (1995).

150 BNF (2004). Nutrient requirements and recommendations, www.nutrition.org.uk.

151 Cruickshank (1975).

152 Sinel (1984). 
Table 4. Estimated average daily requirements (EAR) of energy in kilocalories for people of different ages.

\begin{tabular}{lcc}
\hline Age Group & Males & Females \\
\hline 0-3 Months & 545 & 515 \\
4-6 Months & 690 & 645 \\
7-9 Months & 825 & 765 \\
10-12 Month & 920 & 865 \\
1-3 Years & 1230 & 1165 \\
4-6 Years & 1715 & 1545 \\
7-10 Years & 1970 & 1740 \\
11-14 Years & 2220 & 1845 \\
15-18 Years & 2755 & 2110 \\
19-50 Years & 2550 & 1940 \\
51-59 Years & 2550 & 1900 \\
60-64 Years & 2380 & 1900 \\
65-74 Years & 2330 & 1900 \\
74+ Years & 2100 & 1810 \\
\hline Source: www
\end{tabular}

Source: www.nutrition.org.uk

had any for three months. I would adore a good hunk of Dutch cheese also, and about two dozen eggs would be lovely if you could get them across without breaking them. Even one egg would be very acceptable". ${ }^{153}$

There was also evidence that the growth of children and adolescents was impeded during the occupation. ${ }^{154}$ One Jersey doctor who investigated the growth of school-aged children during the occupation found that all age groups had below average growth rates. ${ }^{155}$ The Education Council agreed, finding in its annual report of 1944 that between December 1943 and January 1944 25\% of children had lost weight, and that between January and February $194433 \%$ had lost weight. ${ }^{156}$ Likewise, the Medical Officer for Health in Jersey found that children aged 6 to 14 were several pounds lighter, on average, in 1943. ${ }^{157}$ There was also evidence of reduced growth in height, since the average height of 14 year olds in 1940 was $5 \mathrm{ft} 1 \mathrm{in}$ $(1.55 \mathrm{~m})$, while in 1943 this was only $4 \mathrm{ft} 10^{1 / 2}$ in $(1.49 \mathrm{~m}) .{ }^{158}$ A subsequent analysis of the Jersey children's growth data, which compared their growth in height and weight during the occupation years with that of children on the mainland UK, ${ }^{159}$

153 Bihet (1985).

154 Rivett (2001).

155 Lewis (1983).

156 Jeffs (1999).

157 Cruickshank (1975).

158 Cruickshank (1975); McLoughlin (1995).

159 Ellison, G. T. H., Kelly, M. (2005). "Growth of Jersey schoolchildren during the 1940-1945 German occupation: comparison with schoolchildren on mainland Britain”, Human Biology, 77: 761-772. 
found that the Jersey children had significantly lower growth rates compared to children in the UK. Shortly after the end of the occupation, the Jersey children's growth rate had caught up in terms of weight, but their rate of growth in height remained below that of children in the UK. This is likely to indicate that either the Jersey children would have remained shorter as adults, or their period of growth would have been extended, thus delaying their development. Finally, there is also evidence that age at menarche was delayed among women resident in Guernsey who reached puberty during the occupation, and this may be further evidence of developmental delay affecting young people exposed to the occupation. ${ }^{160}$

Food deprivation not only manifested itself in poor growth, but also created a number of other health problems. Many children were admitted to hospital in Guernsey suffering from malnutrition, as well as bronchitis and pneumonia brought on by their reduced resistance to disease. ${ }^{161}$ They were also lacking in vitality, so that school gymnastics and sporting events had to be cancelled in order to conserve energy. ${ }^{162}$ Likewise, educational standards were thought to have dropped because there was too little fuel to heat schools, while the children suffered from poor concentration as a result of hunger. ${ }^{163}$ In the final winter of the occupation, all of the islands' state schools were closed from before Christmas until February because of a lack of heating, and when they did reopen it was for only $2^{1 / 2}$ hours per day. ${ }^{164}$ Not surprisingly, by the end of the war the children who had remained on the islands were found to have fallen well behind their evacuated counterparts in terms of their education, and this may well have affected these children well into their later lives. ${ }^{165}$

\section{Summary and Conclusion}

This review found a considerable body of published reports and first-hand accounts which suggests that conditions during the 1940-45 German occupation of the Channel Islands had a number of immediate effects on the health of the population at the time, with an increase in a range of ailments, a decline in growth amongst children and, in certain sections of the population, higher rates of mortality. The sources included in this review also described a serious lack of medical supplies and

160 Fentiman I. S., Allen D. S., Ellison G. T. H. (2007). "The impact of the occupation of Guernsey 1940-1945 on breast cancer risk factors and incidence", International Journal of Clinical Practice, 61: 937-943.

161 Ozanne (1994).

162 Lewis (1983).

163 Jeffs (1999).

164 Sinel (1984).

165 Bunting (2004). 
problems with hygiene, fuel and water, all of which are likely to have exacerbated the decline in health. The deterioration in conditions intensified during the 10 month siege at the end of the war, and mass starvation amongst the civilian population was felt to have been prevented only by the arrival of supplies from the Red Cross. Given the findings of extensive studies examining the longer-term effects of pre- and post-natal exposure to the 'Dutch famine' (also known as the 'Dutch hunger winter') of 1944-1945, ${ }^{166}$ during which comparable levels of deprivation occurred, it is likely that similar long-term health effects may have occurred amongst Channel Islanders - particularly amongst children and young people resident on the Islands throughout the occupation, whose rations appear to have been substantially lower than that currently recommended. This is an issue which the Channel Islands Occupation Birth Cohort Study, and related studies, have set out to address. ${ }^{167}$ The first tranche of analyses from these studies (listed in the Appendix) confirm that individuals exposed to the Channel Islands occupation during childhood and early adulthood experienced delayed growth ${ }^{168}$ and reproductive development, ${ }^{169}$ and have subsequently experienced an increased risk of obesity, ${ }^{170}$ hyperglycaemia, ${ }^{171}$ as well as elevated mortality and higher rates of

166 van Noord, P. A. H. (2004). "Breast cancer and the brain: a neurodevelopmental hypothesis to explain the opposing effects of caloric deprivation during the Dutch famine of 1944-1945 on breast cancer and its risk factors", Journal of Nutrition, 134: 3399S-406S; Painter, R. C., Roseboom, T. J., Bleker, O. P. (2005). "Prenatal exposure to the Dutch famine and disease in later life: an overview", Reproductive Toxicology, 20: 345-352; Kyle. U. G., Pichard, C. (2006). "The Dutch famine of 1944-45: a pathophysiological model of long-term consequences of wasting disease", Current Opinion in Clinical Nutrition and Metabolic Care, 9(4): 388-94; Lumey, L. H., Stein, A. D., Kahn, H .S., van der Pal-de Bruin, K. M., Blauw, G. J., Zybert, P. A., Susser, E. S. (2007). "Cohort profile: the Dutch Hunger Winter families study", International Journal of Epidemiology, 36: 1196-1204.

167 Ellison, G., Jeffs, D., Harhvey, J. (1998). "How did the Occupation Affect the Health of the Channel Islanders?", Channel Islands Occupation Review, 26: 29-43.

168 Kelly, M., Ellison, G. T. H. (2001). "The growth of children on Jersey during the 1940-45 German occupation: Evidence of a negative secular trend?”, Annals of Human Biology, 29: 463-464; Ellison and Kelly (2005).

169 Fentiman et al (2007).

170 Head, R., Gilthorpe, M., Ellison, G. T. H. (2007a). "Obesity among Channel Islanders exposed to a siege in childhood and adolescence a comparison with birthweight", Early Human Development, 83: S160-S161.

171 Travis, R. (1999). Undernutrition in utero, Hyperglycaemia and Hypertension in Later Life Following Exposure to the 1940-45 German Occupation of Guernsey. Hons. Thesis, Department of Biological Anthropology, University of Cambridge, Cambridge; Ellison, G. T. H., Travis, R., Phillips, M. (2001). "Blood pressure and blood glucose concentration amongst middle-aged men conceived and/or born on Guernsey during the 1940-45 German occupation”, Journal of Epidemiology and Community Health, 55 (Suppl 1), A25; Ellison, G. T. H., Travis, R., Phillips, M. (2003). "Blood pressure and blood glucose concentration amongst middle-aged men conceived and/or born on Guernsey during the 1940-45 German occupation", Pediatric Research, $53,25 \mathrm{~A}$. 
hospital admission for cardiovascular disease in later life. ${ }^{172}$ However, there was no evidence that exposure to the occupation was associated with hypercholesterolaemia in later life $\mathrm{e}^{173}$ and the increased risk of hypertension and hyperglycaemia reported previously $^{174}$ has not been replicated in all the cohorts studied to-date. ${ }^{175}$ Nonetheless, these findings do suggest that undernutrition and related deprivation during the 1940-45 Channel Islands occupation had a substantive impact on health in later life. Further research will draw on additional sources detailing conditions during the occupation (including unpublished material held by the Wellcome Library and the Imperial War Museum, and qualitative interviews with surviving islanders), and will extend the range of cohorts examined to include analyses of potential intergenerational effects on reproductive outcomes based on data from vital registration records ${ }^{176}$ and a recently completed questionnaire survey. ${ }^{17}$

Rosemary Head is currently based at the National Centre for Social Research in London and was formerly Senior Research Fellow at St George's, University of London. George Ellison is currently Director of the Graduate School \& Research Office at London Metropolitan University, and was formerly Professor of Health Sciences at St George's, University of London.

\section{Acknowledgements}

Thanks to Dr Darryl Ogier, Don Le Tissier and staff at the States of Guernsey Island Archives Service, without whom many sources for this work could not have

172 Head, R. F., Gilthorpe, M. S., Huntington, A., Ellison, G. T. H. (2006). "Does age at exposure influence the development of cardiovascular disease following the 1944-45 Channel Islands' siege?", Journal of Epidemiology and Community Health, 60: (Suppl 1), A3; Head, R., Gilthorpe, M., Byrom, A., Ellison, G. T. H. (2007b). "Cardiovascular disease and mortality in later life following exposure to the 1944 Channel Islands' siege during childhood and adolescence”, Early Human Development, 83: Suppl.1, S89; Head, R. F., Gilthorpe, M. S., Byrom, A., Ellison, G. T. H. (2008). "Cardiovascular disease in a cohort exposed to the 1940-45 Channel Islands occupation", BMC Public Health, 8: 303.

173 Head, R. F., Gilthorpe, M. S., Ellison, G. T. H. (2009). "Cholesterol levels in later life following exposure to the 1944-45 Channel Islands' siege in childhood and adolescence", Nutrition and Health, 20: 91-104.

174 Travis (1999); Ellison et al. (2001); Ellison et al. (2003).

175 Head, R. F. (2008) Long-term Health Impact of the 1944-45 Channel Islands' Siege. Ph.D. Thesis, St George's, University of London: London.

176 Phillips, M. (1999). Fertility on Guernsey during the 1940-45 German Occupation. Hons. Thesis, Department of Biological Anthropology, University of Cambridge, Cambridge.

177 Kelly Irving, M. (2007). The Health and Social Circumstances of Channel Islanders Exposed to the German Occupation (1940-1945): A Lifecourse Approach to Epidemiology. Ph.D. Thesis, Institute of Education, University of London: London. 
been identified. Thanks too to Dr David Jeffs and colleagues at the Guernsey Board of Health and to Keith Robilliard and colleagues at the Guernsey Greffe for their advice and support throughout this research. This work forms part of the Channel Islands Occupation Birth Cohort Study and related studies which have been generously funded by the Lloyds TSB Foundation for the Channel Islands. 


\section{References}

Anquetil, A. F. (1990). Wartime Memories.

Bell, W. M. (1995). I Beg to Report. Policing in Guernsey During the German Occupation. Guernsey: Guernsey Press.

Bihet, M. (1985). A Child's War: The German Occupation of Guernsey as seen through young eyes. Sparkford: Haynes.

Bihet, M. (1993). Reflections of Guernsey, Guernsey: Guernsey Press.

BNF (2004). Nutrient requirements and recommendations, www.nutrition.org.uk/.

Bunting, M. (2004). The Model Occupation: The Channel Islands under German rule 1940-1945. London: Pimlico.

Cruickshank, C. (1975). The German Occupation of the Channel Islands: The official history of the occupation years. Guernsey: Guernsey Press.

Dales, G. (1995). "True account of relatives under German Occupation in Guernsey in the year 1944". Careless Talk Costs Lives: Memories 1939-1945. Guernsey: Guernsey Women's Institute.

Day, O. (1995). "Extracts from a letter sent by Richard Foley to his mother 12th June 1945". Careless Talk Costs Lives: Memories 1939-1945. Guernsey: Guernsey Women's Institute.

Ellison, G. T. H., Kelly, M. (2005). "Growth of Jersey schoolchildren during the 1940-1945 German occupation: comparison with schoolchildren on mainland Britain”, Human Biology, 77: 761-772.

Ellison, G., Jeffs, D., Harvey, J. (1998). "How did the Occupation Affect the Health of the Channel Islanders?", Channel Islands Occupation Review, 26: 2943.

Ellison, G. T. H., Travis, R., Phillips, M. (2001). "Blood pressure and blood glucose concentration amongst middle-aged men conceived and/or born on Guernsey during the 1940-45 German occupation”, Journal of Epidemiology and Community Health, 55 (Suppl 1), A25.

Ellison, G. T. H., Travis, R., Phillips, M. (2003). "Blood pressure and blood glucose concentration amongst middle-aged men conceived and/or born on Guernsey during the 1940-45”, German occupation. Pediatric Research, 53, 25A.

Fentiman I. S., Allen D. S., Ellison G. T. H.(2007). "The impact of the occupation of Guernsey 1940-1945 on breast cancer risk factors and incidence", International Journal of Clinical Practice, 61: 937-943.

Head, R. F. (2008). Long-term Health Impact of the 1944-45 Channel Islands' Siege. Ph.D. Thesis. St George's: University of London, London. 
Head, R. F., Gilthorpe, M. S., Huntington, A., Ellison, G. T. H. (2006). "Does age at exposure influence the development of cardiovascular disease following the 1944-45 Channel Islands' siege?", Journal of Epidemiology and Community Health, 60: (Suppl 1), A3.

Head, R., Gilthorpe, M., Ellison, G. T. H. (2007a). "Obesity among Channel Islanders exposed to a siege in childhood and adolescence: a comparison with birthweight", Early Human Development, 83: S160-S161.

Head, R., Gilthorpe, M., Byrom, A., Ellison, G. T. H. (2007b). "Cardiovascular disease and mortality in later life following exposure to the 1944 Channel Islands' siege during childhood and adolescence", Early Human Development, 83: Suppl.1, S89.

Head, R. F., Gilthorpe, M. S., Byrom, A., Ellison, G. T. H. (2008). "Cardiovascular disease in a cohort exposed to the 1940-45 Channel Islands occupation", BMC Public Health, 8: 303.

Head, R. F., Gilthorpe, M. S., Ellison, G. T. H. (2009). "Cholesterol levels in later life following exposure to the 1944-45 Channel Islands' siege in childhood and adolescence", Nutrition and Health, 20: 91-104.

Hillsdon, S. (ed.) (1999). A Century of Jersey Memories. Bradford on Avon: Seaflower Books.

Jeffs, D. (ed.) (1999). One Hundred Years of Health: The changing health of Guernsey 1899-1999. Guernsey: Board of Health.

Kelly, M., Ellison, G. T. H. (2001). "The growth of children on Jersey during the 1940-45 German occupation: Evidence of a negative secular trend?”, Annals of Human Biology, 29: 463-464.

Kelly Irving, M. (2007). The Health and Social Circumstances of Channel Islanders Exposed to the German Occupation (1940-1945): A Lifecourse Approach to Epidemiology. Ph.D. Thesis, Institute of Education, University of London: London.

Kyle. U. G., Pichard, C. (2006). "The Dutch famine of 1944-45: a pathophysiological model of long-term consequences of wasting disease", Current Opinion in Clinical Nutrition and Metabolic Care, 9(4): 388-94.

Lainé, A. (1945a). Occupation Diary. Guernsey: Island Archives Service.

Lainé, A. (1945b). Report on Essential Supplies and Services During the Occupation of Guernsey by German Forces and the Work of the Committee. Guernsey: Committee for the Control of Essential Commodities, States of Guernsey. Langlois, A. (1999). Undernutrition in Early Life and Cause of Premature Mortality in Guernsey. Hons. Thesis, Cambridge: Department of Biological Anthropology, University of Cambridge.

Le Ruez, N. (1994). Jersey Occupation Diary. Jersey: Seaflower Books.

Leale, J. (1940-1945). Minutes of the Controlling Committee of the States of Guernsey. Guernsey. 
Lewis, J. (1983). A Doctor's Occupation: The dramatic true story of life in Nazioccupied Jersey. Sevenoaks: New English Library.

Lumey, L. H., Stein, A. D., Kahn, H .S., van der Pal-de Bruin, K. M., Blauw, G. J., Zybert, P. A., Susser, E. S. (2007). "Cohort profile: the Dutch Hunger Winter families study", International Journal of Epidemiology, 36: 1196-1204.

Maugham, R. C. F. (1946). Jersey Under the Jackboot: A first-hand account of the island's ordeal during the German occupation. London: W. H. Allen and Co.

Mayne, R. (1945). Operation "Nestegg": The liberation of Jersey 1945. Jersey: Channel Printers.

McLoughlin, R. (1995). Living With the Enemy: An outline of the German occupation of the Channel Islands with first-hand accounts by the people who remember the years 1940 to 1945. St Helier: Starlight.

Ozanne, B. S. (1994). A Peep Behind the Screens: 1940-1945. Guernsey: Guernsey Press.

Painter, R. C., Roseboom, T. J., Bleker, O. P. (2005). "Prenatal exposure to the Dutch famine and disease in later life: an overview", Reproductive Toxicology, 20: $345-352$.

Rivett, P. J. (2001). A Tiny Act of Defiance. Paignton: Planetesimal.

Salisbury, H. E. (2000). The 900 Days: The siege of Leningrad. London: Pan.

Sanders, P. (2005). The British Channel Islands under German Occupation 1940-45. Jersey: Jersey Heritage Trust.

Sinel, L. (1958). Swastika Over Jersey: An outline of the occupation and the liberation of the island. Guernsey: Guernsey Press.

Sinel, L. (1984). The German Occupation of Jersey: The complete diary of events from June 1940 to June 1945. Jersey: La Haule.

Stein, Z., Susser, M. (1975). "Fertility, Fecundity, Famine: Food rations in the Dutch Famine 1944-5 have a causal relation to fertility, and probably to fecundity", Human Biology, 47: 131-154.

Tabb, P. (2005). A Peculiar Occupation: New Perspectives on Hitler's Channel Islands. Hersham: Ian Allan.

van Noord, P. A. H. (2004). "Breast cancer and the brain: a neurodevelopmental hypothesis to explain the opposing effects of caloric deprivation during the Dutch famine of 1944-1945 on breast cancer and its risk factors", Journal of Nutrition, 134: 3399S-406S.

Victor, L. (2008). "Systematic reviewing", Social Research Update, 54: 1-4.

Wood, A., Wood, M. (1955). Islands in Danger. London: Wyman and Sons. 


\section{Appendix. Publications emanating from the Channel Islands Occupation Birth Cohort Study and related studies}

Available from: www.gthellison.info.

Allen, D. S., Ellison, G. T. H., Dos Santos Silva, I., De Stavola, B. L., Fentiman, I. S. (2002). "Determinants of the availability and accuracy of self-reported birth weight in middle-aged and elderly women", American Journal of Epidemiology, 155(4): 379-384.

Ellison, G. T. H., Kelly, M. (2005). "The growth of Jersey school children during the 1940-45 German occupation: a comparison with school children on mainland Britain", Human Biology, 77: 761-772.

Ellison, G., Jeffs, D., Harvey, J. (1998). "How did the occupation affect the health of the Channel Islanders?", Channel Islands Occupation Review, 26: 29-43.

Ellison, G. T. H., Travis, R., Phillips, M. (2001). "Blood pressure and blood glucose concentration amongst middle-aged men conceived and/or born on Guernsey during the 1940-45 German occupation”, Journal of Epidemiology and Community Health, 55 (Suppl 1): A25.

Ellison, G. T. H., Travis, R., Phillips, M. (2003). "Blood pressure and blood glucose concentration amongst middle-aged men conceived and/or born on Guernsey during the 1940-45 German occupation", Pediatric Research, 53: $25 \mathrm{~A}$.

Fentiman, I. S., Allen, D. S., Ellison, G. T. H. (2007). "The impact of the Occupation of Guernsey 1940-45 on breast cancer risk factors and incidence", International Journal of Clinical Practice, 61: 937-43.

Head, R. F. (2008). Long-term Health Impact of the 1944-45 Channel Islands' Siege. Ph.D. Thesis. St George's: University of London, London.

Head, R., Ellison, G. T. H. (2005) "Sociodemographic determinants of evacuation from Guernsey prior to the 1940-45 German occupation", Annals of Human Biology, 32: 795-797.

Head, R. F., Ellison, G. T. H. (2007a). Home births and birth outcomes: midwifery in pre-war Guernsey. British Journal of Midwifery, 15: 332-336.

Head, R., Ellison, G. T. H. (2007b). "Is the 1940-45 occupation of the Channel Islands a good model for studying the developmental origins of health and disease?", Early Human Development, 83: S148.

Head, R. F., Gilthorpe, M. S., Huntington, A., Ellison, G. T. H. (2006) "Does age at exposure influence the development of cardiovascular disease following the 1944-45 Channel Islands' siege?", Journal of Epidemiology and Community Health, 60 (Suppl 1): A3. 
Head, R., Gilthorpe, M., Ellison, G. T. H. (2007). "Obesity among Channel Islanders exposed to a siege in childhood and adolescence a comparison with birthweight", Early Human Development, 83: S160-S161.

Head, R., Gilthorpe, M., Byrom, A., Ellison, G. T. H. (2007). Cardiovascular disease and mortality in later life following exposure to the 1944 Channel Islands' siege during childhood and adolescence. Early Human Development, 83, S89.

Head, R. F., Byrom, A., Ellison, G. T. H. (2008). "A qualitative exploration of the production Hospital Episode Statistics in a Guernsey hospital: implications for regional comparisons of UK health data", Health Services Management Research, 21: 178-184.

Head, R. F., Gilthorpe, M. S., Byrom, A., Ellison, G. T. H. (2008). "Cardiovascular disease in a cohort exposed to the 1940-45 Channel Islands occupation”, BMC Public Health, 8: 303.

Head, R. F., Gilthorpe, M. S., Ellison, G. T. H. (2009). "Cholesterol levels in later life following exposure to the 1944-45 Channel Islands' siege in childhood and adolescence", Nutrition and Health, 20: 91-104.

Kelly, M., Ellison, G. T. H. (2001). "The growth of children on Jersey during the 1940-45 German occupation: Evidence of a negative secular trend?”, Annals of Human Biology, 29: 463-464.

Kelly, M., Ellison, G. T. H. (2002). "Sociodemographic correlates of the availability and precision of self-reported birthweight: implications for research into the foetal origins of adult disease", Annals of Human Biology, 29: 466.

Kelly Irving, M. (2007). The Health and Social Circumstances of Channel Islanders Exposed to the German Occupation (1940-1945): A Lifecourse Approach to Epidemiology. Ph.D. Thesis, Institute of Education, University of London, London.

Langlois, A. (1999). Undernutrition in Early Life and Cause of Premature Mortality in Guernsey. Hons. Thesis, Department of Biological Anthropology, University of Cambridge, Cambridge.

Phillips, M. (1999). Fertility on Guernsey during the 1940-45 German Occupation. Hons. Thesis, Department of Biological Anthropology, University of Cambridge, Cambridge.

Stoeckl, A. D., Ellison, G. T. H. (2000). "Sociodemographic predictors of low birth weight and perinatal mortality in pre-war Guernsey", Annals of Human Biology, 28: 108-109.

Travis, R. (1999). Undernutrition in utero, Hyperglycaemia and Hypertension in Later Life Following Exposure to the 1940-45 German Occupation of Guernsey. Thesis, Department of Biological Anthropology, University of Cambridge, Cambridge. 